\title{
Sustainability of Cultural Identity of Ex-Adherents Kawula Warga Naluri of 1966-1971 in Banjarnegara, Indonesia
}

\author{
Puji Sulani $^{1 *}$, Priyanto Wibowo², R. Tuty Nur Mutia Enoch Muas ${ }^{3}$ \\ 1 Universitas Indonesia, Indonesia; e-mail: pujisulani81@gmail.com \\ 2 Universitas Indonesia, Indonesia; e-mail: riyanto.wibowo13@gmail.com \\ 3 Universitas Indonesia, Indonesia; e-mail: tutymuas@gmail.com \\ * Correspondence
}

Received: 2021-10-27; Accepted: 2021-12-21; Published: 2021-12-31

\begin{abstract}
This article describes the interaction between the structure and agency of ex-adherent of Kawula Warga Naluri in Banjarnegara District to maintain cultural identity and fight against the stereotype of "belum beragama" (does not belong to any religion) after the September 30th Movement incident in 1965. This article is a study of social history carried out through stages according to the rules of the historical method. The historical sources used are oral, namely historical actors and witnesses combined with written sources. Data obtained were analysed and interpreted using the structuration theory adopted from Giddens. This article produces an explanation of the reciprocal relationship between the structure of religious rules and socio-political conditions with the choice of Buddha Dharma as the religion of ex-adherent of Kawula Warga Naluri. The choice of Buddha Dharma is a form of rejection of the stereotype of "belum beragama" adherence to religious rules and persistence of cultural identity. In adapting to the Buddha Dharma, the ex-adherent of Kawula Warga Naluri face suspicious attitudes from the local government. The ex-adherent of Kawula Warga Naluri responds to this attitude in an accommodative and moderate manner. This article concludes that there is an interaction between structure and the act of disbanding, application of religious obligations, and the defense of cultural identity through Buddha Dharma by ex-adherent of Kawula Warga Naluri.
\end{abstract}

Keywords: Banyumasan; cultural identity; Javanese Buddhists; local religion; September 30th movement.

\begin{abstract}
Abstrak: Artikel ini bertujuan untuk mendeskripsikan interaksi antara struktur dan agensi ekspenghayat Kawula Warga Naluri (KWN) di Kabupaten Banjarnegara dalam menjaga kebertahanan identitas kultural dan dalam melawan stereotip "belum beragama" setelah peristiwa Gerakan 30 September tahun 1965. Artikel ini merupakan kajian sejarah sosial yang dilakukan melalui tahapan sesuai dengan kaidah metode sejarah. Sumber sejarah yang digunakan adalah sumber lisan dari pelaku dan saksi sejarah dipadukan dengan sumber tertulis. Data yang diperoleh dianalisis dan diinterpretasi menggunakan teori strukturasi dari Giddens. Artikel ini menghasilkan penjelasan hubungan timbal balik antara struktur aturan agama dan kondisi sosial politik dengan pilihan Buddha Dharma sebagai agama eks-penghayat Kawula Warga Naluri. Pemilihan Buddha Dharma merupakan bentuk penolakan terhadap stereotip "belum beragama", ketaatan pada aturan agama, dan kebertahanan terhadap identitas kultural. Dalam beradaptasi dengan Buddha Dharma, ekspenghayat Kawula Warga Naluri menghadapi sikap curiga dari pemerintah setempat. Eks-penghayat KWN menyikapi sikap tersebut secara akomodatif dan moderat. Kesimpulan dari artikel ini adalah bahwa terdapat interaksi antara struktur dengan tindakan pembubaran, penerapan kewajiban beragama, dan pertahanan identitas kultural melalui Buddha Dharma oleh eks-penghayat Kawula Warga Naluri..
\end{abstract}

Kata Kunci: Agama lokal; Banyumasan; Buddha Jawa; gerakan 30 september; identitas kultural. 


\section{Introduction}

The belief system dynamics in Indonesia are related to social, cultural, and political changes until the Constitutional Court Decision Number 97/PUU-XIV/2016 is issued. This decision minimises the state's discriminatory beliefs, although the community has not entirely accepted it. Many studies on the ebb and flow of beliefs have been carried out. These studies recommend that religious groups with belief groups reconcile (Ruswanda, 2020). Another study considers that Constitutional Court's decision is still "ambiguous" and leaves population administration problems (Butt, 2020) so it requires followup to ensure its implementation (Nalle, 2021). Previous studies have looked at the struggle of the belief system in political dynamics (Aryono, 2018) and with the discriminatory treatment of the state as part of identity politics (Hakiki, 2011; Ramstedt, 2019). On the other hand, the shift of beliefs reflect the management of religious diversity (Marshall, 2018), especially about issues of citizenship and religious freedom (Apriliyani H., 2020; Hamudy \& Rifki, 2020; Hefner, 2021). Previous studies have described the presence of a belief system that is overshadowed by discriminatory treatment by the state. Although the state accommodates belief flow, it is still distinguished between the terms "belief" and "religion." This regulation is said in Article 29 paragraph (2) of the 1945 Constitution before the amendment, that, "The state guarantees the independence of each resident to embrace their religion and to worship according to their religion and beliefs."

The state's discriminatory treatment of religious beliefs is emphasised through religious criteria in the Regulation of the Ministry for Religious Affairs No. 9 of the year 1952, which does not accommodate beliefs as a religion (Picard, 2020). Since then, the belief system has been labeled as "not a religion," despite the influence of Islam, Christianity, Hinduism, or Buddhism (Ramstedt, 2019). The state's discriminatory attitude is legitimised through Presidential Decree Number 1/PNPS/1965 concerning Prevention of the Abuse and or Blasphemy of Religion. Only six religions were recognised; other religions were allowed to flourish; non-conflicting beliefs also flourished. However, after the September 30th Movement (G/30/S) incident in 1965, adherents of the faith were labeled as "not having religion yet," or "belum beragama", communists, and deemed to have defiled official religion (Colbran, 2010). The government then froze the belief system (Hefner, 2013) and required adherents to embrace a world religion or return to their parent religion (Colbran, 2010). The state's domination of religion and its discriminatory treatment by taking advantage of the G/30/S incident in 1965 affected the conversion of adherents to world religions. As a result, the number of Hindus and Buddhists in Java in 1967 increased by approximately 3\% (Mulder, 1970).

The affiliation of adherents with world religions raises questions of the survival of cultural identity attached to the term belief system. In the early 20th century, the belief system was referred to as a Javanese mysticism, "aliran kebatinan" (Mulder, 1970), "agama Jawi" (Koentjaraningrat, 1984), "agama leluhur" (Watini, 2018), "agama lokal" (MacDonald, 2011) or "spiritual traditions" (Hefner, 2020). Culturally, politically, socially, and philosophically, many studies on the dynamics of the flow of belief have been conducted. The belief system fulfills mental needs and embodies Javanese culture (Mulder, 1970). In addition, it is also an effort to revive and preserve Javanese culture (Patty, 1986) and spirituality that is equal with religion (MacDonald, 2011). Based on the earlier article, it appears that there is a relationship between belief groups and cultural identity. However, earlier studies have not discussed the cultural identity of ex-adherent local beliefs. This article takes a socio-cultural-historical picture of the efforts of ex-adherent local beliefs to keep their cultural identity after the G/30/S incident in 1965.

Several earlier studies have explained the defense of religious and cultural identities of the adherent of the local beliefs. Masade (a local belief system) adherent in the Sangihe Islands, North Sulawesi, keep their identity of Islam and Christianity (Nur et al., 2019). Meanwhile, after the G/30/S incident in 1965, the adherent of Budho Tengger sought refuge in Buddhism and then Hinduism (Oetomo, 2015). The Towani Tolotong (a local belief system) adherent in South Sulawesi affiliated with Hinduism (Sugiarti, 2020), and the Budo adherent of the Sasak ethnic group in North Lombok, took refuge under the auspices of Buddhism (Macdougall, 2005). Earlier studies described the defense of the cultural identity of adherents in world religions. Still, they did not explain the role of agents and the

Puji Sulani, Priyanto Wibowo, R. Tuty Nur Mutia Enoch Muas/Sustainability of Cultural Identity of Ex-Adherents Kawula Warga Naluri of 1966-1971 in Banjarnegara, Indonesia 
interaction between agents' actions and social structures in dealing with state discriminatory treatment. Therefore, this article describes ex-adherent local religious efforts, especially Kawula Warga Naluri (KWN), to keep their cultural identity after the G/30/S incident in 1965.

The name of the Kawula Warga Naluri belief group in its Statutes and bylaws (Anggaran Dasar dan Anggaran Rumah Tangga - AD/ART) is referred to as kekeluargaan (family principles), while its adherent is called warga (inhabitant/resident). Kawula Warga Naluri developed in the early 20th century in Gombong, Kebumen, Central Java and has adherent in the former Banyumas Residency, to Ciamis in West Java (Kartapradja, 1990). The southern part of Banjarnegara District, as part of the former Banyumas Residency, became the site of the development of the KWN in the early 20th century until 1965. After the G/30/S incident in 1965, KWN adherents received a communist stereotype and were labelled as "belum beragama," so they were dissolved. The incident, which is related to the G/30/S incident, raises questions regarding the actions of former KWN adherents after they were disbanded. It is alleged that after 1965, most of the ex-KWN adherents were affiliated with world religions, one of which was Buddhism or Buddha Dharma. This phenomenon is interesting to study historically to get an overview of the dissolution of the KWN and the introduction of ex-KWN adherent with Buddha Dharma comprehensively.

The earlier study about the dynamics of KWN development only touched on the existence of transformation groups from KWN or Naluri, namely Paguyuban Jawa Sejati (PAJATI) and Paguyuban Budaya Bangsa (PBB) (Nafiya, 2019). Another study discusses the historical existence of KWN until its transformation into the Paguyuban Budaya Bangsa in 1920-2016 (Apriliyani H., 2020). This study relates to the spirituality of the adherents to nature as culture and the history of its emergence. However, it does not discuss the efforts of ex-KWN adherents or Naluri's efforts to keep spirituality and culture after the G/30/S incident in 1965. In contrast to the earlier study, this article examines the efforts of exKWN adherents in the Banjarnegara district to keep their cultural identity through Buddha Dharma. The question of this article is how is the interaction between the structure and the agency for the exKWN adherents after being stereotyped as "belum beragama" and disbanded? How is the interaction between the structure and the agency of ex-KWN adherent in producing and reproducing their social structure after being affiliated with Buddha Dharma? The temporal limit begins with the dissolution of the KWN in 1966 until 1971, the last year that former KWN adherents in Banjarnegara District were affiliated with Buddha Dharma. Banjarnegara District became the research site because KWN was influential from the early 20th century until after the G/30/S incident in 1965.

This article uses the historical method with the social history approach to take a picture of the efforts of ex-KWN adherents in keeping their cultural identity after the G/30/S incident of 1965 in more depth. The series of stages of the historical method in this article consists of heuristics, source criticism, interpretation, and historiography (Tosh, 2015). Historical sources are obtained from oral sources and combined with written sources. Oral sources come from perpetrators, historical witnesses, and their descendants, who directly experienced the dissolution of the KWN in Banjarnegara District. Written sources come from contemporary newspapers and magazines obtained from individual collections and digital sources. The historical sources are verified through internal and external criticism considering social, religious, or political backgrounds; involvement of historical actors and witnesses in events; and the authenticity of the source. The reality experienced by ex-KWN adherents after the G/30/S incident in 1965 was analysed by adopting structuration theory (Giddens, 1984). Structuring is how actors or agents produce and reproduce structures in systems and interactions through their actions. This analysis is conducted by studying how social systems involve structures in sustainable activities that agents recreate through rules and resources. According to Giddens, rules and resources are used in producing and reproducing conditions so that actions occur. Giddens's emphasis on structuration is on the "duality of structure," that is, the linking of structure and agency or action that influences each other. The structure in Giddens's thinking is constraining and allows the agent to act or agency so that reproduction occurs. This reciprocal and mutually influencing interaction is known as "dialectics of control" (Giddens, 1984). 


\section{The History and Establishment of Kawula Warga Naluri}

Banjarnegara District became one of the places where KWN developed from the 1930s until the end of 1966. During the Dutch East Indies period, Banjarnegara District became part of the Banyumas Residency, flanked by five regencies from the Banyumas Residency, Kedu Residency, and Pekalongan Residency. The five regencies are Pekalongan and Batang in the north, Wonosobo in the east, Purbalingga and Banyumas in the west, and Kebumen in the south (Badan Pusat Statistik Kabupaten Banjarnegara, 2021). The southern part of Banjarnegara District is a mountainous area of South Serayu. At the same time, in the north, it is a mountainous area of North Serayu and is part of the Dieng plateau (Baperlitbang.banjarnegarakab, 2021). In this area, KWN is developing, mainly in the sub-districts in the southern part, namely Sigaluh, Banjarnegara, Purwonegoro, Mandiraja, and Purworejo/Klampok, as well as Pagentan District in the north. These sub-districts, bordered by Sempor and Karanganyar, are adjacent to the KWN center in Gombong, Kebumen District.

Kawula Warga Naluri was originally known as Santana group founded by Mas Hadi in Bagelen, during his escape from Banyumas prison ("Een Belangrijke Vangst," 1922a; "Een Belangrijke Vangst," 1922b). In a newspaper dated 1933, the Santana group was reported to be led by Mas Hadi since 1919 ("De Santana-Beweging," 1933a; “De Santana-Beweging," 1933b; “De Santana-Beweging," 1933c). When Mas Hadi died in 1942, K.H. Kasbullah from Gandrungmangun, Cilacap District, replaced him with the assistance of Mas Hadi's son, namely R. Noorhadi or Nurhadi. Around 1952 when there was a dispute between K.H. Kasbullah, who wanted to maintain the teachings, with Nurhadi, who wanted to change it, the position of KWN was divided. Kasbullah's group is centered and developed in the west of Kroya, Cilacap, and its surroundings, while Nurhadi's group is centered and developed in Wonokriyo, Gombong, and surrounding areas. However, after K.H. Kasbullah died in 1952, KWN was led by Nurhadi with an administrative center located in Wonokriyo, Gombong (Kartapradja, 1990). Apart from being reported in Dutch-language newspapers, the existence of the Santana group in South Banyumas in the early 20th century was also reported by the Resident of Banyumas, M. Van Zanveld, to the Governor-General J.P. Graaf van Limburg Stirum. In his report dated January 28, 1920, M. Van Zanveld said that the new religion, Santana, was spread by Mohamad Sirad and his sons-in-law, Mas Hadi and Santono. They are from Goemeng Hamlet, Brangkal Village, Gombong; and Tlogodari Village, Gombong, Kedu Residency (Arsip Nasional Republik Indonesia [ANRI], 1981).

At the beginning of its development, the Santana group was known as a new religious movement called "Gerakan Santana." In 1933 Santana's group changed its name to Perkumpulan Kawula Naluri (PKN), similar to the name of the Perkumpulan Kawula Ngajogjakarta group in Yogyakarta ("De Santana-Beweging," 1933a; “De Santana-Beweging," 1933b; “De Santana-Beweging," 1933c). Between the 1940s and 1950s, Perkumpulan Kawula Naluri changed its name to Kawula Warga Naluri. The organisation's name is listed in the AD/ART KWN, dated 1 Rajab 1875 Saka year or around 1942 (Kartapradja, 1990). In the 1950s, the Indisch Missietijdchrift reported the existence of a religious movement called Kawruh Naluri (Wetenschap der voorouders) (Bakker, 1958). The two names are different, but both come from the Santana group (Paratun, personal communication, December 20, 2020). The Santana group or KWN is a peguron with a teacher-centered leadership system, namely Mas Hadi, Bapak Kekeluargaan of KWN (Kartapradja, 1990).

Mas Hadi, calling himself Gusti Amad alias Imam Mahdi (Arsip Nasional Republik Indonesia [ANRI], 1981), is considered and considers himself to be "Ratu Adil" with the title Hadikusumo alias Prince Heru Cokro (Arsip Nasional Republik Indonesia [ANRI], 1981; Hindarto, 2021). The existence of Mas Hadi as Ratu Adil gave hope to people who were depressed and suffering during the Dutch East Indies period (Aprillianti, 2017). Mas Hadi attend had a significant impact on the number of Santana adherents from Gombong and other areas, such as Japara, as well as other cities ("De SantanaBeweging," 1933a; "De Santana-Beweging," 1933b; “De Santana-Beweging," 1933c; Hindarto, 2021). Mas Hadi's popularity spread to the people of Ciamis, West Java (Kartapradja, 1990) and the Banyumas Residency, namely Klampok and Banjarnegara and Sumpiuh, Banyumas. In 1933 it was reported that the people of Klampok, Banjarnegara, and Sumpiuh had come to meet the founder of the "Santana Movement", Mas Hadi or Raden Mashadi, or Raden Mas Hadikusumo (“De Santana-Beweging," 1933a; 
"De Santana-Beweging," 1933b; "De Santana-Beweging," 1933c). The arrival of community was influenced by the figure of Mas Hadi, who was considered the Queen of Justice. On the other hand, the Javanese in the 18th to 19th centuries believed in the presence of Ratu Adil. In 1925 three mystical teachers named Kyai Hasan Maulani, Mas Malangyuda, and Kyai Nurhakim from Cirebon, Banyumas, and Purwokerto, were informed of writing a book about Ratu Adil. All three use the Primbon book to convey information about the coming of Ratu Adil to the people of western Central Java (Koentjaraningrat, 1984). Therefore, there is a connection between the belief in Ratu Adil's arrival and the interest of the people of Klampok, Banjarnegara, and Sumpiuh, who came to meet Mas Hadi. Interaction between the two parties is thought to impact the development of KWN in the Banjarnegara District and Banyumas District.

The religious system (Koentjaraningrat, 1984) or the belief system of the KWN is related to the teachings and views of life that are sourced from hereditary traditions and the teachings of the KWN. Kawula Wawrga Naluri's view of life is based on "divinity, humanity, and kinship according to ancestral will." These principles and beliefs of life are recorded in the organisation's statutes. The KWN view of life is also implied in the organisational identity, Naluri, which means that KWN adherents are a "titah" (command) that must follow the naluri of their ancestors or "follow in the footsteps of Javanese ancestors" (Kartapradja, 1990). The meaning of naluri in the identity of KWN has relevance to the source of the teachings used, namely the mystical Javanese kebatinan (mysticism) book. The origins of these teachings are literary works that are considered to contain elements of Buddhahood, namely Serat Darmagandhul (Kartapradja, 1990), Serat Gatoloco or Suluk Gatholoco (Winarso, personal communication, December 20, 2020; Paratun, personal communication, December 20, 2020), kebatinan magazines (Kasdi, personal communication, December 21, 2020), Sabdopalon magazine (Sastro, personal communication, December 21, 2020), primbon (Radi, personal communication, December 21, 2020), Bhinneka Tunggal Ika, Timbul Djaman, Sepanjang Djaman, and the book Sinar Batin (Kamsianto, personal communication, December 20, 2020; Mahudi, personal communication, December 21, 2020). From these various sources, the meaning of the word "naluri" in the identity of KWN has a relationship with Serat Dharmogandul or Serat Darmagandhul or Serat Dhermagandhul or Suluk Darmagandul. The meaning is that there are instructions to follow in the footsteps of Javanese ancestors with religion and return to Hinduism and Buddhism, as believed by an adherent of the Banjarnegara District KWN (Paratun, personal communication, December 20, 2020; Winarso, personal communication, December 20, 2020; Kamsianto, December 20, 2020). However, previous studies saw Serat Darmagandul as a literary work illustrating the struggle of kejawen and Islam (Drewes, 2013). Another study assesses the literary work as a form of sentimental attitude towards Islam (Ricklefs, 2012) because it contains religious conflicts and prejudices during the transition from Hinduism and Buddhism to Islam (Riyadi, 2013) and contains criticism and is contrary to Islamic teachings (Sururin \& Moh. Muslim, 2016). However, the values of these foundational normative resources are used as an adherent of KWN in carrying out their spiritual and Javanese cultural identity.

Kawula Warga Naluri adherents have organisational, religious, and Javanese traditions or customs activities. Organisational activities are carried out through regular meetings every 35 days on Selasa Manis nights in the Javanese calendar at the Wonokriyo sanggar pamujan, Gombong. Religious activities such as malam satu suro commemoration, sembahyang, and semadi are carried out in conjunction with a ritual called a slametan (Geertz, 1976; Koentjaraningrat, 1984). On malam satu suro, KWN adherents carry out religious activities to commemorate the Javanese New Year and KWN'S day (Paratun, personal communication, December 20, 2020) and kekeluargaan deliberations (Kartapradja, 1990). Concerning their ancestors, KWN adherents perform ancestral tilik leluhur or visit ancestral graves or nyekar and nyadran in the month of Ruwah in the Javanese calendar (Radi, personal communication, December 21, 2020; Mahudi, personal communication, December 21, 2020). On the other hand, adherents of KWN have a standard religious system with other Javanese people, namely doing slametan to commemorate the cycle of life, slametan on Selasa, and Jumat Kliwon nights, and maintaining relations with their ancestors by placing offerings. Life cycle warnings, for example, on birthdays are carried out based on neptu, namely counting the number of days and good dates in the

Puji Sulani, Priyanto Wibowo, R. Tuty Nur Mutia Enoch Muas/Sustainability of Cultural Identity of Ex-Adherents Kawula Warga Naluri of 1966-1971 in Banjarnegara, Indonesia 
Javanese calendar based on sacred numbers (Paratun, personal communication, December 20, 2020; Ahmadi, personal communication, December 21, 2020). Concerning marriage, KWN adherents perform a wedding ceremony according to Javanese custom or customs and traditions of KWN adherents and then legalised according to the KWN method (Kartapradja, 1990); Paratun, personal communication, December 20, 2020; Literature, personal communication, December 21, 2020).

In the 1950s, since being led by Nurhadi, KWN began to be managed as an organisation through the establishment of AD/ART, financial management, and the construction of central and regional activity buildings. At the central level, in about 1957, a sanggar pamujan building, a padepokan, and a school building were built. In each area, sanggar pamujan were built, such as in Kawedanan Kutowinangun, Banjarnegara District, and others (Kartapradja, 1990); Kamsianto, personal communication, December 20, 2020). The existence of sanggar pamujan in several places shows the popularity of KWN in the areas of the Banyumas Residency and Kedu Residency. The KWN adherents are scattered in places like Lumajang, East Java; Metro, Lampung; and Pati, Central Java (Kartapradja, 1990). In Banjarnegara District, KWN adherents reside in several villages in certain sub-districts, such as Mertasari and Merden, Purwonegoro District; Mandiraja Wetan, Mandiraja Kulon, and Somawangi, Mandiraja District; Brayut, Sigaluh District (Kamsianto, personal communication, December 20, 2020); and Sokaraja, Kasmaran, Pagentan, Aribaya, Pagentan District. In each sub-district or kawedanan, KWN is managed by kesepuhan (Paratun, personal communication, December 20, 2020), appointed directly by the Bapak Kekeluargaan (Kartapradja, 1990). The distribution of KWN adherents in Banjarnegara District occurred at different times and influenced each other. The KWN belief entered Klampok and Banjarnegara in 1933 and developed in the surrounding sub-districts or kawedanan such as Purwonegoro, Mandiraja, and Sigaluh. In 1959, the people of Pagentan District began to know KWN from Mandiraja District through a mystical magazine. In 1960 in the area, precisely in the Windusari hamlet, a sanggar pamujan was established, the center for KWN activities at the sub-district or kawedanan level (Sastro, personal communication, December 21, 2020; Wahyono, personal communication, December 21, 2020).

The Klampok and Banjarnegara people followed the KWN belief in 1933, so it became the structure and religious system of some Banjarnegara people. That is occurred because of the reciprocal interaction between the structure and the agency. In Giddens's structure concept, KWN belief consists of rules and teachings of life views and resources, namely $\mathrm{KWN}$, sanggar pamujan, agents, and adherent. The dimensions of the significant structure are owned by KWN actors, namely Mas Hadi, K.H. Kasbullah, and Nurhadi in his capacity as the Bapak Kekeluargaan, knowledgeable and understanding KWN. The domination structure is owned by actors in controlling for reciprocally allocative resources, namely is $\mathrm{KWN}$, infrastructure, and rules or teachings. Agents and adherents of the local KWN Banjarnegara District are the authoritative resources. Based on this domination structure, actors and agents have a legitimacy structure to control the normative basis, teachings, rules, and sanctions against agents and KWN adherents. Local agents produce and transform teachings, views of life, and values reciprocally to the local KWN adherent of Banjarnegara District. Through the reciprocal interaction between the $\mathrm{KWN}$ structure and the agency of belief following the teachings of the KWN, the adherent reproduces their social actions so that KWN trust develops in Banjarnegara District.

\section{Disbandment of Kawula Warga Naluri}

Social and political dynamics after the G/30/S incident in 1965 had an impact on the belief system for some adherents. Dissolution of the KWN belief in Banjarnegara District in 1966 was a form of the effects of the G/30/S incident in 1965. Disbandment was based on the definition of religion and "not a religion" because KWN was considered a belief, not a religion (Paratun, personal communication, December 20, 2020). Acceptance and response to the definition of KWN as a belief and not a religion represents the cultural values held by rural communities. The response is related to the orientation of Javanese cultural values held by KWN adherents in the 1950s who did not think about the nature of life, even though some studied Javanese classics. Based on the orientation of these cultural values, the Javanese, in facing the difficulties of life, tend to "menerima keadaan" (acceptance) (Koentjaraningrat, 
1984). This value is held by KWN adherents against the "belum beragama" stereotype, namely accepting that their religious system is associated with politics and communist issues. On the other hand, the definition of religion is more accommodating to world religions, while "non-religious" marginalises KWN with stereotypes as "non-religious."

After being disbanded at the end of 1966, ex-KWN adherents were directed to religion by following one of the world religions. Through local government indoctrination, ex-KWN adherents are encouraged and "required" to choose one religion, between Islam, Christianity, Catholicism, Hinduism, and Buddhism (Paratun, personal communication, December 20, 2020; Radi, personal communication, December 21, 2020). The incident of ex-KWN adherents choosing a religion is a form of structural duality that influences each other between the local government structure and their agencies so that KWN adherents are religious and the agency is KWN adherents in choosing one religion. The government structure includes a structure of significance in understanding religious rules, a domination structure in controlling KWN adherents to be dissolved and choose a religion, and a legitimacy structure to provide sanctions or directions if KWN adherents are not religious. This structure restrains KWN adherents from being religious but gives them the freedom to choose without imposing a particular religion.

Ex-KWN adherents choose one of the world's religions as their cultural and social identity through internal negotiations between the central and regional KWN. The Bapak Kekeluargaan, Nurhadi, played an essential role in producing actions based on religious rules and reproducing them through negotiations with KWN resources. Nurhadi plays a role in controlling the resources of KWN adherents because of the government's structure of domination and legitimacy. His adherent disperses, becomes religious, and chooses a religion between Hindu Dharma or Buddha Dharma (Paratun, personal communication, December 20, 2020). The legitimacy structure of the Bapak Kekeluargaan was followed up by internal negotiations between the kesepuhan ex-KWN adherents in Banjarnegara District. At the end of 1966, former KWN adherents agreed to choose Buddha Dharma (Paratun, personal communication, December 20, 2020; Kasdi, personal communication, December 21, 2020). Internal negotiations for the ex-KWN adherent of Banjarnegara District were carried out with the kesepuhan conducting deliberation to determine the religion of choice. Based on intern negotiations and the legitimacy structure of the Bapak Kekeluargaan, an ex-KWN adherent of Banjarnegara District, especially in three sub-districts, namely Purwonegoro, Mandiraja, and Pagentan, agreed to choose Buddha Dharma (Kamsianto, personal communication, December 20, 2020). Choosing Buddha Dharma is a form of rejection of former KWN adherents against the stereotype of "belum beragama." The refusal was accommodated by accepting the rules to be religious or "beragama." Ex-KWN adherents carry out agency or accept religious rules affiliated with Buddha Dharma. This action is a form of defensive attitude, as adherents of belief accept discrimination based on the definition of religion and "nonreligion," as a political impact of 1965 (Nur et al., 2019; Oetomo, 2015; Sugiarti, 2020).

\section{Buddha-Dharma: The Religious Struggle of Ex-adherent Kawula Warga Naluri}

After the disbandment of KWN, leader of ex- KWN adherents provided a normative basis for their follower to choose Hindu Dharma or Buddha Dharma. Based on considerations of religious rules, cultural identity, and the structure of the KWN, local agents, namely the sesepuh of Banjarnegara District, decided to choose Buddha Dharma as a religion. Ex-KWN adherents in Banjarnegara District chose Buddha Dharma based on the structure of the significance of the KWN actor, the legitimacy structure of the KWN, and the religious belief of their ancestors namely Buddha Dharma. By choosing Buddha Dharma as a religion, KWN believes that they have preserved and continued the religion of their ancestors (Paratun, personal communication, December 20, 2020). The choice of Buddha Dharma is following the sesepuh' teachings that one-day KWN adherents shall return to the old religion of their ancestors, namely Buddha Dharma (Winarso, personal communication, December 20, 2020). Ex-KWN adherents believe that Buddha Dharma shall re-emerge in Indonesia. Therefore, $\mathrm{KWN}$ is considered a bridge so that its adherent can quickly enter when Buddha Dharma appears (Sukardi, personal 
communication, December 21, 2020). The messages of the sesepuh and the teachings of KWN are sourced from Serat Darmagandhul and Serat Gatoloco, which contain elements of Buddhahood. On the other hand, both contain stories about the decline of Hinduism and Buddhism during the Majapahit Kingdom and the reappearance of Budhi, which some Javanese people believe to be the reappearance of Hinduism and Buddhism. The messages and teachings of the ancestors became the basis for the exKWN adherent of Banjarnegara District in choosing Buddha Dharma.

The Bapak Kekeluargaan, rules, and resources KWN encourages his adherent to follow their ancestors' footsteps by practicing Buddhism. One of the sources of these rules comes from Javanese and Buddhist mystical teachings, namely Serat Darmagandhul and Serat Gatoloco. The study of Wieringa (2019) underlines three things related to Suluk Gatoloco, a work of poetry with a satire nuanced antiIslam and a form of defense of Javanese culture, so that Javanese people "return to the origins" and not leave their original religion. Returning to early religion is interpreted by Wieringa as returning to the era of the original religion of the Javanese. The meaning of the two serat are that Javanese people return to their original religion correlates with the teachings of KWN, which control their adherence to follow in the footsteps of Javanese ancestors. This meaning is related to the cultural identity of the belief system as a means of preserving ancestral culture. KWN's belief in following in the footsteps of Javanese ancestors is in line with the study of religious beliefs as an effort to "reawaken and preserve an articulated culture through religious activities and Javanese cultural traditions" (Patty, 1986). Negotiations for ex-KWN adherents to affiliate with Buddha Dharma are based on Serat Darmagandhul and Serat Gatoloco, which alludes to Buddha Dharma before Islam and the structure of the Bapak kekeluargaan teachings and KWN rules, to follow in the footsteps of Javanese ancestors.

The ex-KWN adherents' choice to be affiliated with Buddha Dharma results from formalising their status as "beragama" people. After stating that they chose Buddha Dharma, former KWN adherents studied and searched for the existence of a Buddhist Dharma institution. In the early 20th century until the late 1950s, Buddha Dharma in Central Java had only developed in the east, while in the west, especially in rural farming communities, it had not yet developed. However, in 1967 the existence of 3,000 Buddhist Dharma adherents was reported to be in the Purwodadi area, Kebumen, under the coordination of Kardjono Dipo ("Madjalah Buddhis Sinar Borobudur, Tahun II No. 9 1967," 1967). Kardjono Dipo became the initial source for the ex-KWN adherent of Banjarnegara District to adapt to the Buddha Dharma. Paratun, Sadikin, and Tasan Hadi Nuryono were the first agents to ngangsu kawruh or studied Buddha Dharma and became adherent of Kardjono Dipo (Kamsianto, personal communication, December 20, 2020). Paratun became an agent who built the structure of the Buddha Dharma, especially in Purwonegoro District. Knowledge of Buddha Dharma and the requirements for the inauguration to become adherents was not only obtained from Kardjono Dipo. The Indonesian Buddhist office in Semarang is for Paratun (personal communication, December 20, 2020), Sadikin, and Tarsa Hadimulyono (Kamsianto, personal communication, December 20, 2020), in negotiation so that ex-KWN adherents can be affiliated with Buddha Dharma. Communication and negotiations for the ex-KWN adherent of Banjarnegara District were also carried out by contacting Cipto Wardoyo, namely the coordinator of Buddha Dharma for Banyumas, Kedu, Magelang, and Pajajaran regions (Mahudi, personal communication, December 21, 2020) located in Buntu, Sidamulya, Kemranjen Subdistrict, Banyumas District (Kamsianto, personal communication, December 20, 2020).

Guided by the rules from the Indonesian Buddhist Secretary-General, Upasaka Silasurya, and Buddhist Dharma religious activity book, namely Pancaran Bahagia and Bhadra Santi, Paratun conveyed the results of the negotiations to the elders of former KWN adherent (Paratun, personal communication, December 20,2020). The elders and ex-KWN adherents held deliberations and negotiations in each subdistrict to form a structure and committee for the inauguration of Buddha Dharma. Former devotees of KWN Mandiraja Sub-district have deliberations at Pendopo Agung, a former community centre for KWN Somawangi (Kamsianto, personal communication, December 20, 2020). Approximately in July or August between 1967 and 1968, Buddha Dharma was inaugurated in Purwonegoro and Mandiraja subdistricts through Buddhist religious ceremonies and the inauguration of Buddha Dharma administrators in the presence of the local government (Paratun, personal communication, December 
20, 2020; Winaro, personal communication, December 20, 2020; Kamsianto, personal communication, December 20, 2020). Unlike the former KWN adherent in the previous two sub-districts, the time required for former KWN adherents in Pagentan District to build the structure of Buddha Dharma is longer. The former KWN adherents in the sub-district were affiliated with Buddha Dharma in 1967 and 1969. The figures who led the negotiation process for selecting Buddha Dharma in the sub-district were Singantana, Samireja, Sawirya, and Achmadi (Wahyono, personal communication, December 21, 2020; Sukardi, personal communication, December 21, 2020). The inauguration of Buddha Dharma in the sub-district was carried out in Windusari Hamlet, Sokaraja Village, in 1971 under the influence of Buddha Dharma, Purwonegoro District, and Somawangi District (Sukardi, personal communication, December 21, 2020; Wahyono, personal communication, December 21, 2020).

Establishing a Buddhist Dharma structure in district Banjarnegara to maintain cultural identity through Buddha Dharma requires adaptation that is not easy. The ex-KWN adherents received an a priori and suspicious attitude from the local government during the inauguration of Buddha Dharma. The apriori and suspicion impact intimidation and threats, especially against agents who are ex-KWN adherents. Ex-KWN adherents are suspected of being a sect of forbidden beliefs, one of which is from Mbah Suro's Padepokan (Paratun, personal communication, December 20, 2020). Mbah Suro's Padepokan is a belief group based in Nginggil Village, Kawedanan Randublatung, Blora, Central Java which is affiliated with the Indonesian Communist Party (PKI) (Aryono, 2018). The suspicious attitude of the local government has resulted in discomfort for ex-KWN adherents in adapting to the Buddha Dharma. Therefore, before it was inaugurated, former KWN adherents studied Buddhist Dharma rituals in secret. The government's suspicion of ex-KWN adherents also occurred during the inauguration of Buddha Dharma in the area. The lack of communication with the government and misunderstandings caused the inauguration of the Buddha Dharma to be stopped. Guests and Buddhist Dharma leaders from Semarang were examined and detained for one day, while the committee chairman was a political prisoner for half a year. After officially embracing Buddha Dharma, the apriori and suspicion from the local government were also experienced by ex-KWN adherents. When Buddha Dharma was not known to the public, Buddhist Dharma figures in Banjarnegara Regency secretly introduced ritual procedures because local authorities would come to them if there were a crowd. In the early days of broadcasting Buddha Dharma, agents also accepted the suspicious attitude of the local government by questioning the identity and legality of broadcasting. Government Security Agents overcame suspicions of religious activities by submitting a letter of assignment to the Indonesian Buddhist administrator in Gombong, Kebumen (Kamsianto, personal communication, December 20, 2020; Paratun, personal communication, December 20, 2020).

The ex-KWN adherent of Banjarnegara District received a different structure and agency from the local government in dissolving KWN and choosing a religion. The suspicious attitude of local government during the adaptation process of ex-KWN adherents with Buddha Dharma shows the structure of domination in conducting the legitimacy structure of the rules so that they are religious. The suspicious attitude of local government is not balanced with the structure of significance in the form of understanding and knowledge from the local government of the newly developed religion in the region. However, this structure gives freedom to ex-KWN adherents or new adherents of Buddha Dharma, who accommodatively accept and obey the rules. The struggle of ex-KWN adherents in dealing with structures reflects the freedom to keep their cultural identity to continue the message and teachings of their ancestors through Buddha Dharma. The willing attitude of ex-KWN adherents in accepting religious rules is like the Tengger community in keeping their religious identity through Hinduism (Oetomo, 2015).

\section{Interaction of Structure and Agency in Defense of Cultural Identity of Ex Kawula Warga Naluri adherents}

The duality of the structure of Giddens becomes an analytical tool to answer the questions in this article. This analysis focused on the interaction between structure and agency of ex-KWN adherents when they received the stereotype of "belum beragama" disbanded in 1966, until when they built the

Puji Sulani, Priyanto Wibowo, R. Tuty Nur Mutia Enoch Muas/Sustainability of Cultural Identity of Ex-Adherents Kawula Warga Naluri of 1966-1971 in Banjarnegara, Indonesia 
structure of Buddha Dharma from 1966 to 1971. The structure is a completeness of the social system in rules and resources. The structure consists of significance, dominance, and legitimacy. The structure presents social practices that function as knowledge agents to produce and reproduce actions. The agent's ability or capacity is the structure of significance. This structure is shown in the structure of domination in the production and reproduction of structural interactions with agents or powers in controlling rules and resources. Resources consist of allocative resources, namely objects, objects, or material, and authoritative resources, namely agents. The legitimacy structure justifies the agent's actions in implementing social behavior control tools and providing normative sanctions (Giddens, 1984). Through this analysis, this article theoretically aims to describe the reciprocal interaction between the structure and agency of ex-adherent KWN in Banjarnegara District in maintaining the survival of cultural identity, fighting the stereotype of "belum beragama" after the G/30/S incident in 1965, as well as in producing and reproducing structures after being affiliated with Buddha Dharma.

The cultural identity of an ex-KWN adherent of Banjarnegara District is reflected in religion, customs, and traditions. In Hall's (1990) thought, cultural identity is formed based on shared historical and cultural experiences that are dynamic and constantly changing. The cultural identity of ex-KWN adherents was formed and changed in the geographical space of Banjarnegara District. This cultural identity was formed before and after the G/30/S incident in 1965. Space and time in Giddens's (1984) thought means interacting and carrying out social practices. In the context of this article, space and time are meaningful for the ex-KWN adherents to maintain their cultural identity. The survival of the cultural identity of ex-KWN adherents is intertwined with Buddha Dharma. In Giddens's (1984) concept of structural duality, the persistence of this identity occurs because of repeated and reciprocal interactions between the structure of religious rules, KWN's structure, Buddha Dharma's structure, and local government agencies, figures, agents, and KWN adherent through negotiation, accommodation, and socio-religious behavior. Practically, this article contributes to reconciliation between the government and the broader community, with local communities maintaining cultural identity through beliefs and religions.

\section{Conclusions}

In general, the disbandment of Kawula Warga Naluri and the imposition of religious obligations for the ex-KWN adherents in Banjarnegara District is a form of interaction between restraining structures. The namely structure are religious rules, local government's power over religious rules that control KWN adherents, and ex-adherent through discriminatory actions against adherent, although moderate in giving freedom to choose religion. This moderate attitude is not restrained by providing opportunities for the ex-KWN adherents to reproduce the structure in choosing a religion. Local exKWN adherents in Banjarnegara District also interact with structure and agency. KWN Bapak kekeluargaan can decide on actions based on the restrictive KWN rules and resources so that his adherent follow their ancestors' footsteps and choose Buddha Dharma as their religion. However, this restraint is reproduced by ex-KWN adherents in determining the choice of religion and origin of Buddha Dharma which can accommodate their cultural identity to follow in the footsteps of their ancestors. Affiliation with Buddha Dharma is a form of agency for the ex-KWN adherents to negotiate their cultural identity to survive. The cultural identity of an ex-KWN adherent of Banjarnegara District is attached to the identity of Buddhist Dharma adherent as a representation of obedience to follow in the footsteps of Javanese ancestors. These findings provide insight into the importance and need for moderation and the reciprocal interaction between agency and structure in dealing with issues of cultural identity, minority and majority issues, and other citizenship issues.

Acknowledgments: The author expresses his gratitude to ex-KWN adherent, their descendants, and Buddhists in Banjarnegara District who share to become informants and facilitate the author in collecting data. The author also expresses his gratitude to STABN Sriwijaya Tangerang Banten for their financial assistance in writing this article.

Conflicts of Interest: : In this article published in the journal Wawasan: Jurnal Ilmiah Agama dan Sosial Budaya, the author, states no conflict of interest from any party. If there are parties who claim this paper in the future, then the whole responsibility lies on the author.

Puji Sulani, Priyanto Wibowo, R. Tuty Nur Mutia Enoch Muas/Sustainability of Cultural Identity of Ex-Adherents Kawula Warga Naluri of 1966-1971 in Banjarnegara, Indonesia 


\section{References}

Apriliyani H., Z. (2020). Dari Konversi ke Resistensi: Strategi Kebertahanan Agama Lokal dalam Pusaran Terbatas. FUADUNA: Jurnal Kajian Keagamaan Dan Kemasyarakatan, 01(02), 43-54.

Aprillianti, C. K. (2017). Aliran Kepercayaan Paguyuban Budaya Bangsa di Desa Wonokriyo Kecamatan Gombong Kabupaten Kebumen Tahun 1920-2016. Universitas Sebelas Maret Surakarta.

Arsip Nasional Republik Indonesia [ANRI]. (1981). Laporan-Laporan Tentang Gerakan Protes di Jawa pada Abad XX. Jakarta: Arsip Nasional Republik Indonesia.

Aryono, A. (2018). Pergulatan Aliran Kepercayaan dalam Panggung Politik Indonesia, 1950an-2010an: Romo Semono Sastrodihardjo dan Aliran Kapribaden. Jurnal Sejarah Citra Lekha, 3(1), 58. https://doi.org/10.14710/jscl.v3i1.17855

Badan Pusat Statistik Kabupaten Banjarnegara. (2021). Kabupaten Banjarnegara dalam Angka 2021. Banjarnegara: Badan Pusat Statistik Kabupaten Banjarnegara.

Bakker, J. W. M. (1958). Nieuwe Godsdiensten in Indonesia: Indisch Missietijdschrift (41st ed.). Den Haag: Indische Missie Vereeniging.

Baperlitbang.banjarnegarakab. (2021). Geografis Kabupaten Banjarnegara.

Butt, S. (2020). Constitutional recognition of beliefs in Indonesia. Journal of Law and Religion, 35(3), 450-473. https://doi.org/10.1017/jlr.2020.39

Clifford Geertz. (1976). The Religion of Java. Chicago: University of Chicago Press.

Colbran, N. (2010). Realities and challenges in realising freedom of religion or belief in Indonesia. International Journal of Human Rights, 14(5), 678-704. https://doi.org/10.1080/13642980903155166

De Santana-Beweging. (1933a, January). De Locomotief, p. 3.

De Santana-Beweging. (1933b, January). Algemeen Handelsblad Voor Nederlandsch-Indie, p. 9.

De Santana-Beweging. (1933c, February). Deli Courant Dagblad Voor Sumatra, p. 6.

Drewes, G. W. J. (2013). The struggle between Javanism and Islam as illustrated by the Serat Dermagandul. Bijdragen Tot de Taal-, Land-En Volkenkunde / Journal of the Humanities and Social Sciences of Southeast Asia, 122(3), 309-365. https://doi.org/10.1163/22134379-90002925

Een belangrijke vangst. (1922a, March). Bataviaasch Nieuwsblad, p. 1.

Een belangrijke vangst. (1922b, April). Rotterdamsch Nieuwsblad, p. 6.

Giddens, A. (1984). Constitution of the Society. Berkeley, CA.: University of California Press. https://doi.org/10.1144/transglas.13.1.118

Hakiki, K. M. (2011). Politik Identitas Agama Lokal: Studi Kasus Aliran Kebatinan. Al-Adyan, XI(1), 159-174.

Hall, S. (1990). Cultural Identity and Diaspora: Identity: Community, Culture, Difference. In J. Rutherford (Ed.), Identity: Community, Culture, Difference (p. 225). Lawrence \& Wishart.

Hamudy, M. I. A., \& Rifki, M. S. (2020). Civil Rights of the Believers of Unofficial Religions (Penghayat Kepercayaan) in Pekalongan District. Jurnal Antropologi: Isu-Isu Sosial Budaya, 22(1), 48. https://doi.org/10.25077/jantro.v22.n1.p48-59.2020

Hefner, R. W. (2013). the Study of Religious Freedom in Indonesia. Review of Faith and International Affairs, 11(2), 18-27. https://doi.org/10.1080/15570274.2013.808038

Hefner, R. W. (2020). Islam and Covenantal Pluralism in Indonesia: A Critical Juncture Analysis. Review of Faith and International Affairs, 18(2), 1-17. https://doi.org/10.1080/15570274.2020.1753946

Hefner, R. W. (2021). Islam and institutional religious freedom in indonesia. Religions, 12(6). https://doi.org/10.3390/rel12060415

Hindarto, T. (2021). Wetan Kali Kulon Kali: Mengenang Kabupaten Karanganyar Hingga Penggabungan dengan Kabupaten Kebumen 1936. Yogyakarta: deepublish.

Kartapradja, K. (1990). Aliran Kepercayaan dan Kepercayaan di Indonesia. Jakarta: Haji Masagung.

Koentjaraningrat. (1984). Kebudayaan Jawa. Jakarta: PN Balai Pustaka.

MacDonald, M. N. (2011). The primitive, the primal, and the indigenous in the study of religion. Journal of the American Academy of Religion, 79(4), 814-826. https://doi.org/10.1093/jaarel/lfr081

Macdougall, J. M. (2005). Buddhist Buda or Buda Buddhists? Conversion, Religious Modernism and Conflict in the Minority Buda Sasak Communities of New Order and Post-Suharto Lombok (UMI Dissertation Services; Vol. 44). UMI Dissertation Services. https://doi.org/10.2320/materia.44.24

Madjalah Buddhis Sinar Borobudur, tahun II No. 9 1967. (1967). Buddhis Indonesia, 14-14.

Marshall, P. (2018). The Ambiguities of Religious Freedom in Indonesia. The Review of Faith E International Affairs, 16(1), 85-96. https://doi.org/10.1080/15570274.2018.1433588

Mulder, J. A. N. (1970). Aliran Kebatinan as an Expression of the Javanese Worldview. In Source: Journal of Southeast Asian Studies (Vol. 1).

Puji Sulani, Priyanto Wibowo, R. Tuty Nur Mutia Enoch Muas/Sustainability of Cultural Identity of Ex-Adherents Kawula Warga Naluri of 1966-1971 in Banjarnegara, Indonesia 
Nafiya, S. K. (2019). Nature as Culture of Penghayat: The Landscape, Reaction, and Movement of Penghayat in Cilacap. ETNOSIA : Jurnal Etnografi Indonesia, 4(2), 127. https://doi.org/10.31947/etnosia.v4i2.7653

Nalle, V. I. W. (2021). The Politics of Intolerant Laws against Adherents of Indigenous Beliefs or Aliran Kepercayaan in Indonesia . Asian Journal of Law and Society, 1-19. https://doi.org/10.1017/als.2020.54

Nur, M., Azis, I., Pelestarian, B., Budaya, N., Beringin, B., Manado, K., \& Utara, S. (2019). Agama Lokal Di Kawasan Perbatasan: Kepercayaan Masade' Di Kepulauan Sangihe (Local Religion in the Border Area : Masade 'in the Sangihe Islands ).

Oetomo, S. B. (2015). Strategi Akomodatif Komunitas Tengger Dalam Mempertahankan Identitas Keagamaannya. Smart, 1(1), 27-40. https://doi.org/10.18784/smart.v1i1.227

Patty, S. A. (1986). 'ALIRAN KEPERCAYAAN': A SOCIO-RELIGIOUS MOVEMENT IN INDONESIA - ProQuest. Washington State University, ProQuest Disertations Publishing.

Picard, M. (2020). Kebalian: Konstruksi Dialogis Identitas Bali. Jakarta: Kepustakaan Populer Gramedia.

Ramstedt, M. (2019). Politics of Taxonomy in Postcolonial Indonesia: Ethnic Traditions between Religionisation and Secularisation. Historical Social Research, 44(3), 264-289. https://doi.org/10.12759/hsr.44.2019.3.264-289

Ricklefs, M. C. (2012). Islamisation in Java to c. 1930. In Islamisation and Its Opponents in Java: A Political, Social, Cultural and Religious History, c. 1930 to the Present (Vol. 1, pp. 1-576). Singapore: NUS Press.

Riyadi, M. I. (2013). Kontroversi Theosofi Islam Jawa Dalam Manuskrip Kapujanggan. Al-Tahrir, 13(1), $21-41$.

Ruswanda, A. S. (2020). Indonesian Constitutional Court'S Decision No. 97/Puu-Xiv/2016: a Chance To Encourage Reconciliation Between "Agama" and "Kepercayaan". Religi: Jurnal Studi Agama-Agama, 16(1), $18-41$. https://doi.org/10.14421/rejusta.2020.1601-02

Sugiarti. (2020). Dinamika Komunitas Hindu Towani Tolotang di Sulawesi Selatan. Purwadita: Jurnal Agama Dan Budaya, 4(1), 23-32.

Sururin, \& Moh. Muslim. (2016). Islam dan Kesusastraan Jawa Telaah Kepustakaan Jawa Pada Masa Mataram. Jurnal Bimas Islam, 11(1), 135-164.

Tosh, J. (2015). The Pursuit of History: Aims, Methods and New Directions in The Study of History (6th ed.). London and New York: Routledge.

Watini. (2018). Living in Harmony Between Muslim and Buddhist: Comparative Study: Indonesia and Southeast Asia. Aceh Anthropological Journal, 2(1), 1-26.

Wieringa, E. P. (2019). A nativist defence of Javanism in late 19th-century Java: The Suluk Gatoloco and its co-texts in the Serrat Suluk Panaraga compilation. Indonesia and the Malay World, 47(139), 335-352. https://doi.org/10.1080/13639811.2019.1652436

(C) 2021 by the authors. Submitted for possible open access publication under the terms and conditions of the Creative Commons Attribution (CC BY SA) license (https://creativecommons.org/licenses/by-sa/3.0/). 